\title{
Persistence of soil organic matter and soil structure
}

\author{
${ }^{1}$ W. E. H. BLUM, ${ }^{1,2}$ G. J. LAIR and ${ }^{1}$ J. SCHIEFER \\ ${ }^{1}$ Institute of Soil Research, University of Natural Resources and Life Sciences (BOKU), \\ Vienna \\ ${ }^{2}$ Institute of Ecology, University of Innsbruck
}

\section{Introduction}

The persistence of soil organic matter (SOM) can be defined as resistance against biological decomposition, expressed as residence time in soils. Under this aspect, two types of SOM can be distinguished: biogenic organic matter derived from organic feedstock through biological decomposition (metabolisation, mineralisation) processes, and pyrogenic organic matter, produced through thermochemical fractionation in the absence of oxygen at high temperatures.

SCHMIDT et al. (2011) published the mean residence time of bulk SOM distinguishing between SOM derived from plant material, that of microbial origin and from different biological sources on one side, and pyrogenic (fire-derived) organic matter (biochar) on the other.

From these data it became clear that the mean residence time of biogenic SOM is on average less than 50 years, often less than 20 years, whereas the pyrogenic organic matter shows a considerably higher residence time.
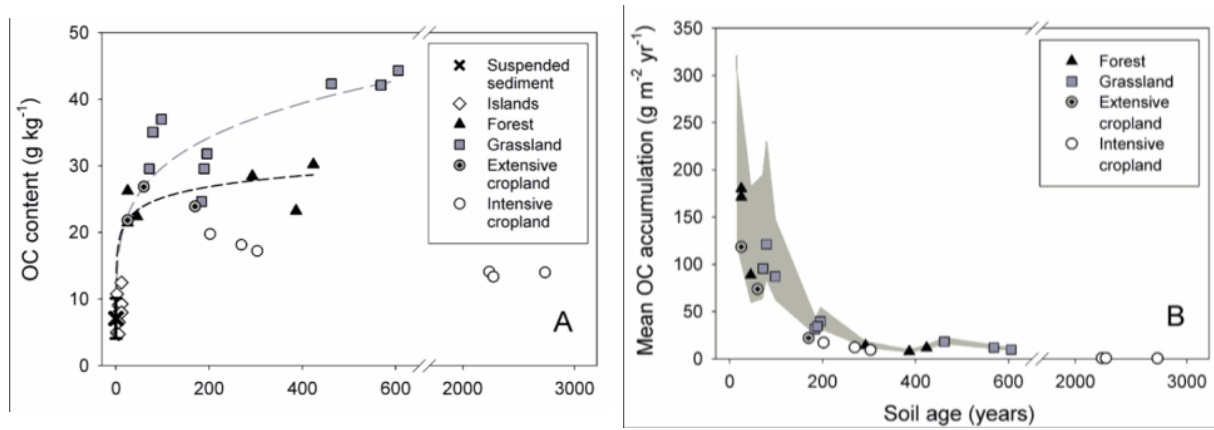

Fig. 1

Organic carbon accumulation in topsoils $(0-20 \mathrm{~cm})$ affected by different land uses (A) and rates of SOM accumulation (B) in the investigated topsoils (ZEHETNER et al., 2009)

Correspondence to: WINFRIED E. H. BLUM, Institute of Soil Research, University of Natural Resources and Life Sciences (BOKU), Peter-Jordan-Str. 82. 1190 Vienna. Austria.

E-mail: winfried.blum@boku.ac.at 
Looking into the radiocarbon-dated SOM in various soil size fractions or physical-chemical humus fractions reveals that some SOM may reach a thousand to several thousand years of age.

A previous study by ZEHETNER et al. (2009) showed an increase in organic carbon (OC) in $\mathrm{g} / \mathrm{kg}$ bulk soil with the soil age (yr) and the mean accumulation of OC in $\mathrm{g} \cdot \mathrm{m}^{-2} \cdot \mathrm{yr}^{-1}$ in the bulk soils under different land uses (Fig. 1). These data indicate that the accumulation of $\mathrm{OC}$ during soil formation occurs very rapidly during the first 50-100 years but decreases quickly in the following years. Therefore, the question arises what is the reason for fast accumulation and the difference in persistence of SOM and how this phenomenon can be explained. In the following, only the persistence of biogenically derived SOM will be discussed.

\section{Material and methods}

\section{Research area and soils}

Within the EU-research project "Soil Transformations in European Catchments" (SoilTrEC, Grant No. 244118), focusing on Critical Zone research, this question was followed up, concentrating specifically on the clay-sized soil fractions (here called "micro-aggregates") of a Chernozem chronosequence with different land uses (forest, pasture, agricultural cropland), ranging in age from a few years to more than eight thousand years. This Chernozem chronosequence developed on Danube sediments in the Marchfeld area, east of Vienna (see Fig. 2).

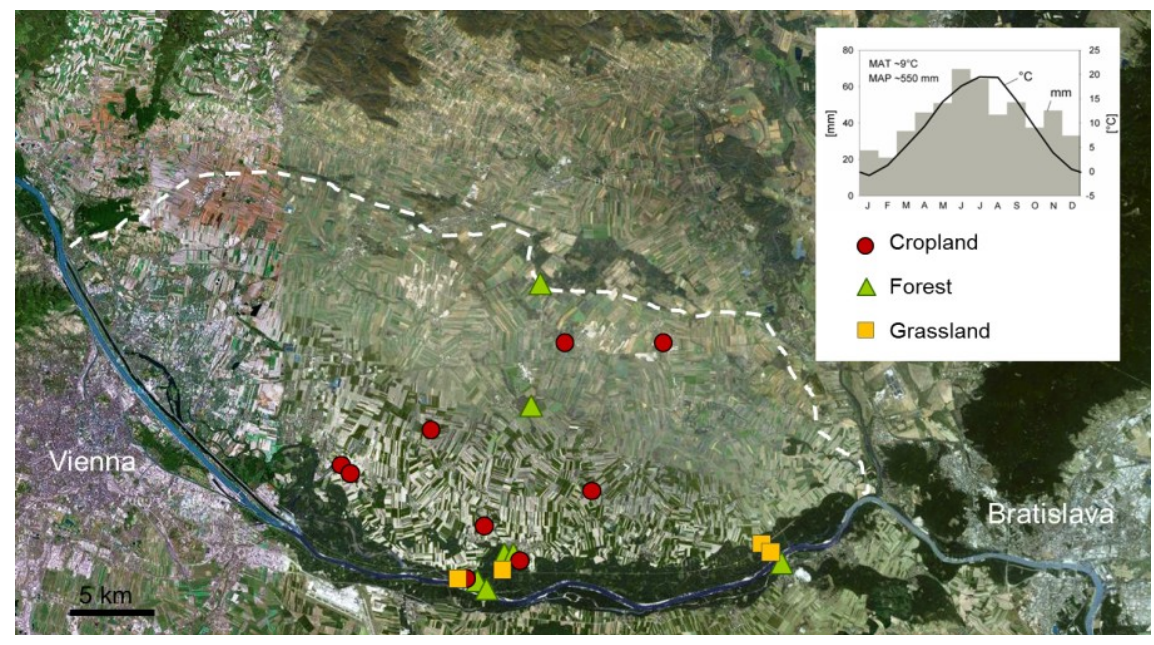

Fig. 2

Critical Zone Observatory (CZO) Marchfeld, located east of Vienna. The study area was bordered in the south by the River Danube, which created the former floodplain with fine sediments (indicated with white-dotted line) during the Holocene 

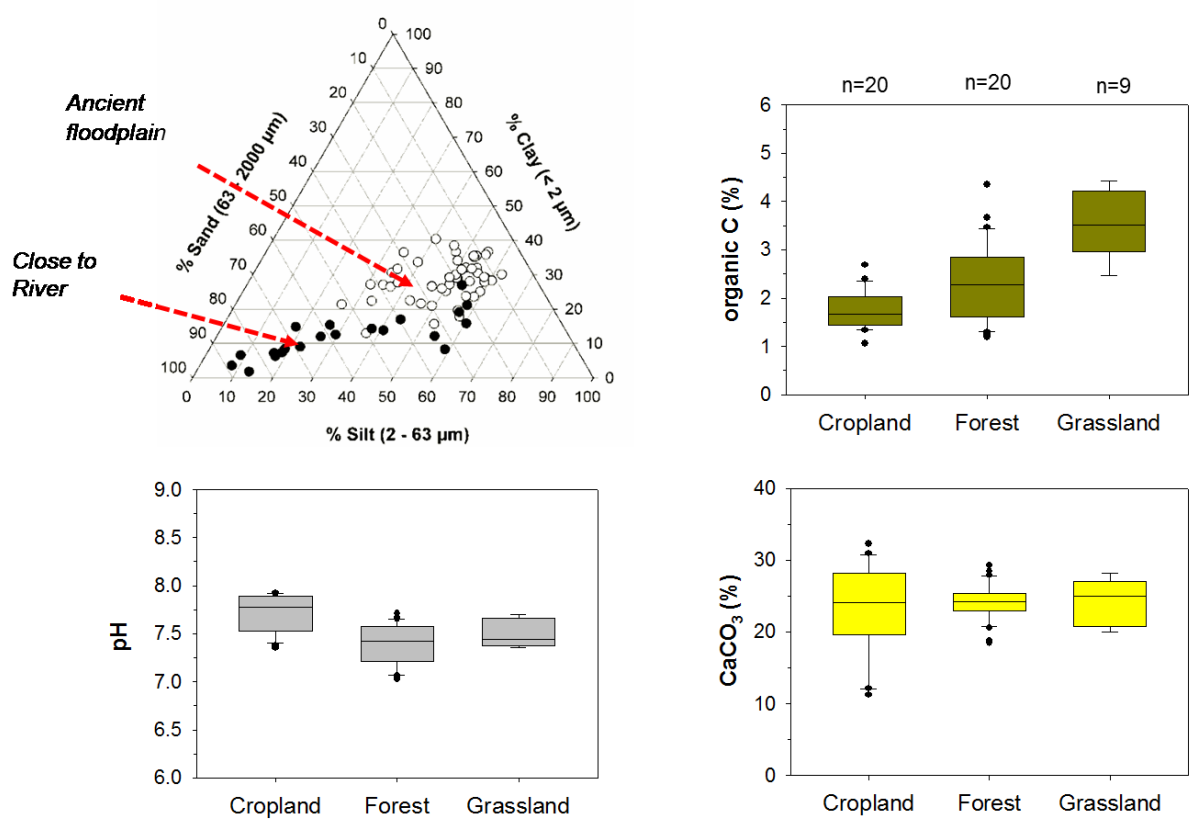

Fig. 3

Soil texture, $\mathrm{pH}\left(\mathrm{H}_{2} \mathrm{O}\right)$, organic $\mathrm{C}$ and $\mathrm{CaCO}_{3}$ content in topsoils $(0-20 \mathrm{~cm})$ under different land uses in the study area

Within this chronosequence, the age of the soils increases with increasing distance from the Danube River, ranging from the youngest soils on fresh sediments to Chernozems more than eight thousand years old (BANWART et al., 2012). The soil age was dated using ${ }^{137} \mathrm{Cs}$, optically stimulated luminescence (OSL), the crystallinity of Fe-oxides (Feo/Fed) and archeological remnants (LAIR et al., 2009).

The texture, $\mathrm{pH}\left(\mathrm{H}_{2} \mathrm{O}\right)$, organic $\mathrm{C}$ and $\mathrm{CaCO}_{3}$ content of the top soils $(0-20 \mathrm{~cm})$ of the investigated chronosequence are shown in Fig. 3.

\section{Research concept and methods}

In order to answer the question of SOM persistence, the aging of SOM with time was analysed in clay-sized "micro-aggregates" $(<2 \mu \mathrm{m})$ in the topsoils, based on the working hypothesis that the resistance of SOM to biological decomposition depends primarily on their capacity to bind at mineral surfaces.

To gain the clay-sized aggregates from the topsoil $(0-10 \mathrm{~cm})$, a particle size fractionation method was chosen according to MONROZIER et al. (1991) and STEMMER et al. (1998). The bulk soil was treated with ultrasonication (55 Watt for 200 seconds) to disrupt the macro-aggregates without harming the micro-aggregates. 
The suspension was centrifuged at $150 \mathrm{~g}(834 \mathrm{rpm})$ for 2 minutes. The supernatant was centrifuged again at $10000 \mathrm{~g}(7400 \mathrm{rpm})$ for 25 minutes. The residue $(2 \mu \mathrm{m}-$ $0.1 \mu \mathrm{m})$ was freeze-dried for subsequent analysis.

The SOM characterisation for selected study sites was performed with Simultaneous Thermal Analysis (STA) and by solid state cross-polarisation magic angle spinning (CPMAS) 13C NMR spectroscopy.

The STA heated up the soil samples to $600{ }^{\circ} \mathrm{C}$ and measured the constant weight loss. The weight loss in specific temperature ranges gives information about the quality of SOM in the soil samples: thermo-labile organic matter was gained between 190 and $390^{\circ} \mathrm{C}$, while thermo-stable organic matter was gained between 390 and $600{ }^{\circ} \mathrm{C}$ due to increased humification/polymerisation (DE LA RosA et al., 2008).

The intensity of NMR signals is proportional to the concentration of the nuclei creating the signal (KNICKER \& NANNY, 1997). These signals are separated into different chemical shift regions and assigned to organic groups: Carboxyl 220-160 ppm; Aryl 160-110 ppm; O-alkyl 110-45 ppm; Alkyl 45-0 ppm.

\section{Results and discussion}

Development of OC in clay-sized micro-aggregates in the topsoils under different vegetation covers along the chronosequence

Fig. 4 shows the accumulation of $\mathrm{OC}$ in clay-sized micro-aggregates over time.

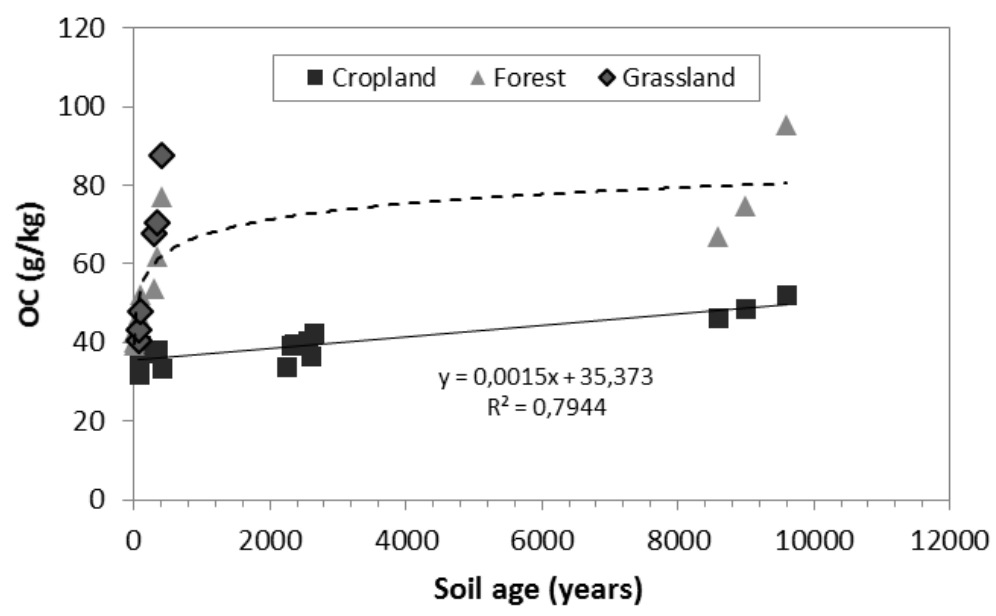

Fig. 4

Organic carbon contents in clay-sized "micro-aggregates" in topsoils of different age and land use. Forest "micro-aggregates" quickly reached an equilibrium level, whereas cropland "micro-aggregates" showed a steady increase with soil age 
Especially under forests, an equilibrium can be argued towards an age of about eight thousand years, whereas under cropland a steadily increasing OC level can be observed for more than eight thousand years, with a measured increase of $1.5 \mathrm{mg}$ $\mathrm{OC} \cdot \mathrm{kg}^{-1}$ soil $\cdot \mathrm{yr}^{-1}$. However, studied croplands have been cultivated for a minimum of 120 years to a maximum of 800 years, which points to a co-evolution of SOM pools and new mineral surfaces during pedogenesis.

Based on this observation, all further analyses were concentrated on the cropland top soils. Grassland soils revealed high OC accumulation rates similar to those under forests. Unfortunately, no soil samples were available at older sites along the chronosequence.

Stabilisation of the OC in the clay-sized fraction of cropland soil based on thermogravimetric analysis

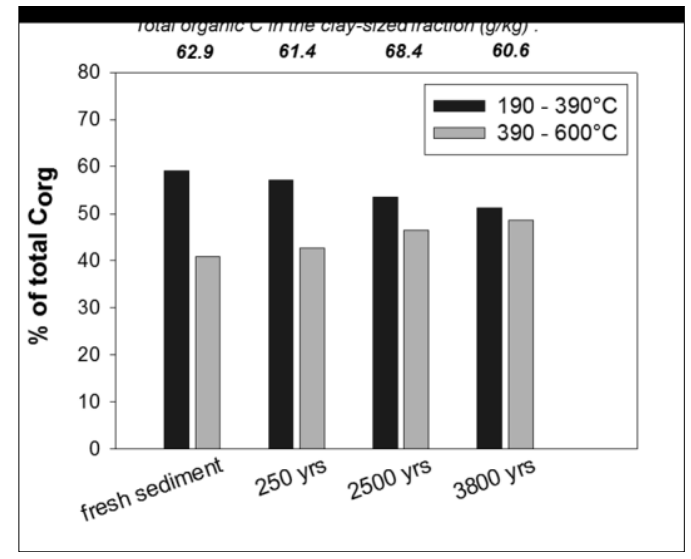

Fig. 5

Stabilisation of organic carbon in the clay-sized "micro-aggregates" of cropland soils $(<2 \mu \mathrm{m})$ during soil formation $\left(190-390{ }^{\circ} \mathrm{C}=\right.$ thermo-labile organic matter; $390-600{ }^{\circ} \mathrm{C}=$ thermo-stable organic matter)

The results from STA analysis on selected sites in the CZO Marchfeld area showed a clear relationship between thermo-labile (190-390 $\left.{ }^{\circ} \mathrm{C}\right)$ and thermo-stable OC $\left(390-600{ }^{\circ} \mathrm{C}\right)$ changes with soil age, with a constant increase in the thermostable fraction with time (Fig. 5).

Changes in the persistence of specific OC compounds as revealed by ${ }^{13} \mathrm{C}-N M R$

From Fig. 6 it became evident that organic compounds that are more resistant to biodegradation, such as Carboxyl-C and Aryl-C, representing mainly acids, amides and aromatic groups (e.g. lignin), increase with time, whereas more easily biodegradable compounds in the O-Alkyl C group (e.g. polysaccharides) and the Alkyl-C group, which includes lipids and hemicellulose, decrease. 


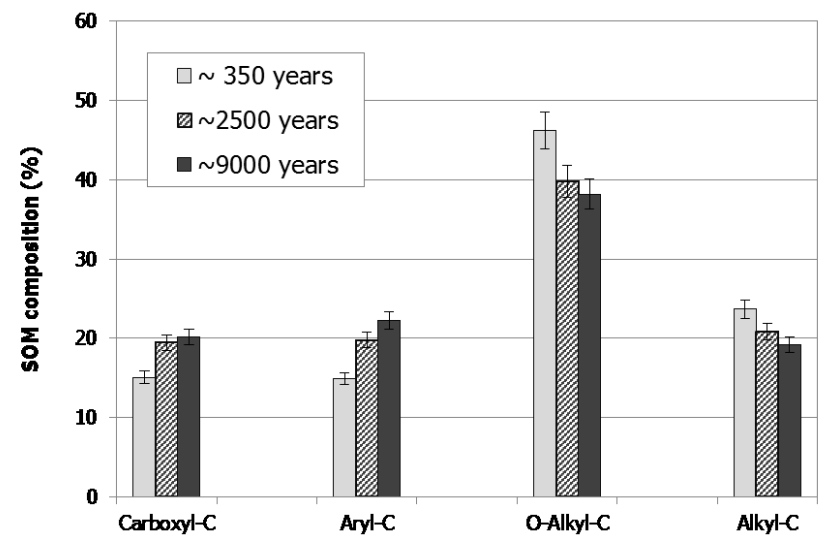

Fig. 6

${ }^{13} \mathrm{C}$-NMR characterisation of selected clay-sized "micro-aggregates" $(<2 \mu \mathrm{m})$ in topsoils $(0-10 \mathrm{~cm})$ under cropping in the CZO Marchfeld area

\section{Conclusions}

The changes observed in the total content and in the biophysical and biochemical composition of OC in the clay-sized "micro-aggregates" in Chernozem topsoils revealed that the $\mathrm{OC}$ in the clay-sized fractions became increasingly more stable with time. This indicates that there are biophysical and biochemical mechanisms that increase the persistence and therefore the age of the OC in soils. This process may be related to changes in the volume and size of soil aggregates, and concomitantly, the volume and size of soil pores, which may influence the access of microbes to the $\mathrm{OC}$ over time.

\section{Summary}

The persistence of SOM was investigated in a dated Chernozem chronosequence on Danube sediments east of Vienna, analysing changes in the total content, thermo-stability and biochemical composition of organic matter in the clay-sized "micro- aggregates" $(<2 \mu \mathrm{m})$ in cropland topsoils $(0-10 \mathrm{~cm})$ with soil age.

The results indicate some of the biophysical and biochemical processes behind the aging and increasing persistence of organic matter in soils. There is a fast accumulation of $\mathrm{OC}$ in the $<2 \mu \mathrm{m}$ micro-aggregates in the first years of soil development under forest and grassland sites, which levels off after $\sim 350$ years. Cropland sites show a steady but not strong increase along the chronosequence.

Soil organic matter composition was analysed with Simultaneous Thermogravimetric Analysis (STA) and 13C NMR and showed the expected changes with increasing soil age. 
Both the thermo-labile SOM pool (i.e. mass loss between 190 and $380{ }^{\circ} \mathrm{C}$ ) and the carboxyl and Alkyl-C pools showed a strong decrease, while the thermal-stable SOM pool (mass loss between $380{ }^{\circ} \mathrm{C}$ and $600^{\circ} \mathrm{C}$ ) and the Aryl-C pool increased with soil age in the $<2 \mu \mathrm{m}$ micro-aggregates.

Keywords: soil chronosequence, SOM persistence, Chernozem, clay-sized fractions, biophysical and biochemical changes.

This research was funded by the EU FP7-ENV-2009 Project SoilTrEC "'Soil Transformations in European Catchments" (Contract no. 244118).

We thank the members of the laboratories at the Institute of Soil Research at BOKU for their help with measurements, Franz Ottner for technical assistance with STA, Markus Steffens for his support and assistance with C13-NMR and Eva Maria Wild for performing radiocarbon dating on soil samples.

\section{References}

Banwart, S., Menon, M., Bernasconi, S. M., Bloem, J., Blum, W. E. H., De Souza, D. M., Davidsdotir, B., Duffy, C., Lair, G. J., Kram, P., Lamacova, A., Lundin, L., Nikolaidis, N. P., Novak, M., Panagos, P., Ragnarsdottir, K. V., Reynolds, B., Robinson, D., Rousseva, S., De Ruiter, P., van GaAns, P., WeNG, L. P., White, T. \& ZhANG, B., 2012. Soil processes and functions across an international network of Critical Zone Observatories: Introduction to experimental methods and initial results. CR GEOSCI. 344. (11-12) 758-772.

De la Rosa, J. M., Knicker, H., López-CAPel, E., Manning, D. A. C., GonzÁlezPerez, J. A. \& GonZÁlez-Vila, F. J., 2008. Direct detection of black carbon in soils by Py-GC/MS, carbon-13 NMR spectroscopy and thermogravimetric techniques. Soil Science Society of America Journal. 72. (1) 258-267.

KNICKER, H. \& NANNY, M. A., 1997. Nuclear magnetic resonance spectroscopy. Basic theory and background. In: NMR Spectroscopy in Environmental Science and Technology. (Eds.: NANnY, M. A., Minear, R. A. \& LenheER, J. A.) 3-15. Oxford University Press. London.

Lair, G. J., Zehetner, F., Hrachowitz, M., Franz, N., MARinger, F.-J. \& GERZABeK, M. H., 2009. Dating of soil layers in a young floodplain using iron oxide crystal1linity. Quaternary Geochronology. 4. 260-266.

Monrozier, L. J., Ladd, J. N., FitzPatrick, R. W., Foster, R. C., Raupach M., 1991. Components and microbial biomass content of size fractionations in soils of contrasting aggregation. Geoderma. 49. 37-62.

Schmidt, M. W. I., Torn, M. S., Abiven, S., DitTMar, T., Guggenberger, G., JANSEns, I. A., KLeber, M., KöGel-Knabner, I., Lehmann, J., Manning, D. A. C., Nannipieri, P., Rasse, D. P., Weiner, S. \& TRUmbore, S. E., 2011. Persistence of soil organic matter as an ecosystem property. Nature. 478. (7367) 49-56. 
Stemmer, M., GerzabeK, M. H. \& Kandeler E., 1998. Organic matter and enzyme activity in particle-size fractions of soils obtained after low-energy sonication. Soil Biology and Biochemistry. 30. (1) 9-17.

Zehetner, F., LAir, G. J. \& GERZABEK, M. H., 2009. Rapid carbon accretion and carbon pool stabilization in floodplain soils. Global Biochemical Cycles. 23. GB4004. 